\title{
Investigation of Oxalate Levels in Sorrel Plant Parts and Sorrel-Based Products
}

\author{
Jema Tuazon-Nartea, Geoffrey Savage
}

Food Group, Faculty of Agriculture and Life Sciences, Lincoln University, Canterbury, New Zealand.

Email: savage@lincoln.ac.nz

Received February $5^{\text {th }}, 2013$; revised March $5^{\text {th }}, 2013$; accepted March $12^{\text {th }}, 2013$

Copyright (C) 2013 Jema Tuazon-Nartea, Geoffrey Savage. This is an open access article distributed under the Creative Commons Attribution License, which permits unrestricted use, distribution, and reproduction in any medium, provided the original work is properly cited.

\begin{abstract}
The oxalate content of the leaves and stems of green and variegated cultivars of sorrel (Rumex acetosa) were extracted and measured using HPLC chromatography. The larger, more mature leaves of both cultivars contained higher levels of total, soluble and insoluble oxalates. The stems also contained appreciable levels of oxalates. The mean soluble oxalate content of the variegated leaves was $14.7 \%$, which was significantly higher than found in the leaves of the green-leaved cultivar (11.9\%). The proportion of soluble oxalate to total oxalate in the stems ranged from $12.7 \%$ to $24.4 \%$ for both cultivars. Sorrel sprouts contained a much higher proportion of soluble oxalates than the green sorrel leaves but were similar in oxalate content to the variegated leaves. Pesto and soup made from sorrel leaves retained their characteristic sour taste despite containing much lower levels of oxalates. The levels of oxalates in sorrel leaves were high and it was recommended that the leaves should be consumed occasionally as a delicacy because of their unique taste rather than as a significant part of the diet. However, the products made from sorrel leaves were less of a problem as they contained lower levels of oxalates.
\end{abstract}

Keywords: Total; Soluble and Insoluble Oxalates; Sorrel Leaves; Pesto; Soup

\section{Introduction}

Sorrel (Rumex acetosa) is a long-lived perennial plant belonging to the large and diverse Polygonaceae family. Green and variegated sorrel varieties are grown as garden herbs or vegetables in Europe but they are also widely distributed in parts of Asia [1]. Sorrel has been used in herbal medicine to treat cutaneous diseases [2] while the flowers contain phenolic compounds which have antiproliferative and tumour arresting effects $[3,4]$; extracts from the aerial parts of the plant show strong antiviral activity [5]. Sorrel is widely mentioned in gardening and recipe books because of its distinctive sour taste, which is attributed to its high oxalate content. Oxalates are responsible for creating desirable flavours in some foods [6]; the tartness of sorrel blends well with a variety of ingredients such as meat, cheese and milk. Sorrel sprouts and young immature leaves have a more subtle flavour and so are suitable for addition to salads and sandwiches. The more mature leaves are normally cooked and added to soups and stews and used to make sauces such as pesto.

Sorrel leaves are a good source of macronutrients and micronutrients $[7,8]$ and it has been suggested that sorrel leaves could be used as an economic source of plantbased protein [7] as they appear to be nutritionally superior to spinach leaves [9]. Although rich in minerals [8], the presence of high levels of the anti-nutritive factor, oxalic acid, reduces the bioavailability of some of the minerals, such as calcium. The risk of consuming foods high in soluble oxalates has been well documented [10]. This has prompted numerous studies seeking to identify methods of reducing the absorption of soluble oxalates $[10,11]$. Oxalate accumulation in the leaves is affected by different factors such as soil conditions, climate, species or cultivar, and maturity. Interesting studies on oxalate accumulation as a function of maturation stage $[12,13]$ and regrowth [14] reveal different results depending on the type of plant investigated. There are few studies on the oxalate content of Rumex acetosa leaves, along with other Rumex species, but the effect of leaf size as a measure of the maturity of the leaf was not investigated in these studies.

The objective of this study was to investigate the distribution of oxalates in the leaves and stems of two culti- 
vars of sorrel (green and variegated), as a function of leaf size. The oxalate content of sorrel sprouts and two common sorrel dishes, soup and pesto were also investigated.

\section{Materials and Methods}

\section{Harvesting and Preparation}

Leaves with stems were harvested from green and variegated sorrel (Rumex acetosa) plants. Fresh samples were sorted according to size (small, medium, large) before separating the leaves from the stems. The length of the leaves was measured. Hydroponically grown green sorrel sprouts were purchased from Kipp's Patch Microgreens, Marshlands, Christchurch, NZ. The total length of the sprouts was not measured. The sprouts, consisting of leaves, stems, and some seeds, were analysed as a single sample. Commercial sorrel pesto was purchased from Fresh Gardens Ltd., Kumeu, West Auckland, NZ. It was a blend of spinach, sorrel, parmesan cheese, olive oil, garlic, salt and pepper. However, the proportion of ingredients in this product was not specified on the product label. Homemade sorrel pesto and sorrel soup were prepared by following the recipes given below:

\begin{tabular}{ll}
\hline Spicy sorrel pesto & Romanian sorrel soup \\
$80 \mathrm{~g}$ large green sorrel leaves & $46 \mathrm{~g}$ large green sorrel \\
$40 \mathrm{~g}$ garlic cloves & leaves \\
$40 \mathrm{~g}$ ground walnuts & $50 \mathrm{~g}$ chopped onions \\
$8 \mathrm{~g}$ chili sauce & $6 \mathrm{~g}$ olive oil \\
$1 / 2$ cup $(60 \mathrm{~g})$ grated & $28 \mathrm{~g}$ sour cream \\
parmesan cheese & $12 \mathrm{~g}$ ground rice \\
10 g olive oil & $1 \mathrm{egg}$ yolk $(\approx 18 \mathrm{~g})$ \\
$6 \mathrm{~g}$ salt and 2 g pepper & $6 \mathrm{~g}$ salt \\
\hline
\end{tabular}

All the ingredients were placed in a blender and processed for one minute. The Romanian soup mix was then placed in a fry pan and simmered for five minutes until cooked. The homogenized pesto or the pesto soup were then frozen at $-18^{\circ} \mathrm{C}$, then freeze-dried in a freeze dryer (W.G. Cuddon Ltd., Blenheim, Marlborough, NZ) and then finely ground in a coffee mill (Sunbeam, model EM0400, China).

\section{Chemical Analysis}

\subsection{Moisture Content Analysis}

The moisture content analysis was carried out by following the AOAC method 935.10 [15].

\subsection{Extraction of Total Oxalates}

For the extraction of the total oxalic acid, $0.2 \mathrm{~g}$ of ground freeze-dried pure sample (leaves, stems and sprouts) or $0.5 \mathrm{~g}$ for the soup and pesto samples was weighed accu- rately into a $100 \mathrm{ml}$ flask and $40 \mathrm{ml}$ of $0.2 \mathrm{M} \mathrm{HCl}$ was added, then the flask was covered with aluminium foil. The mixture was incubated with shaking for 20 minutes at $80^{\circ} \mathrm{C}$. After cooling, each mixture was transferred to a $100 \mathrm{ml}$ volumetric flask and made up to volume with 0.2 $\mathrm{M} \mathrm{HCl}$. Three extractions were carried out on each sample. Fifty $\mathrm{ml}$ of the aliquot was transferred in a $50 \mathrm{ml}$ centrifuge tube then centrifuged at $3500 \mathrm{rpm}$ for $15 \mathrm{~min}$ utes. The liquid sample was filtered through a $0.45 \mu \mathrm{m}$ cellulose acetate syringe filter (Sartorious Ltd., Göttingen, Germany) into a HPLC vial for analysis of the oxalic acid concentration.

\subsection{Extraction of Soluble Oxalates}

For the extraction of the soluble oxalic acid, the same procedure utilized in the extraction for total oxalic acid was followed except that nanopure water (Arium $611 \mathrm{uv}$, Sartorius Ltd., Germany) was used to extract the soluble oxalates.

\subsection{HPLC Analysis of Oxalic Acid}

The oxalic acid concentration of the extracts was determined using an HPLC method [16] where a $20 \mu \mathrm{l}$ of sample extract was analysed using a $300 \times 7.80 \mathrm{~mm}$ Rezex ion exclusion column (Phenomenex Inc., CA, USA) using an isocratic elution, at $0.6 \mathrm{ml} / \mathrm{min}$. with $0.025 \mathrm{M}$ sulphuric acid (HPLC Grade, Baker Chemicals, Phillipsburg, NJ, USA) as a mobile phase. The HPLC system consisted of a Spectra-Physics Isocratic pump and a Spectra-Physics UV/V detector set at $210 \mathrm{~nm}$. Data capture was performed using PeakSimple version 3.59 (SRI Instruments, Torrance, California). The oxalate peak was identified by comparison of the retention time with an oxalate standard $(99.999 \%$, Sigma, St. Louis, MO, USA). Insoluble oxalate was calculated as the difference between the total oxalate (acid extract) and soluble oxalate (water extract) [17].

\subsection{Standard Calibration}

Standard curves, containing 2 - $20 \mathrm{mg}$ oxalic acid/100ml in water and $0.2 \mathrm{M} \mathrm{HCl}$ were prepared and used to quantitate the soluble and total oxalic acid content of samples, respectively.

\section{Statistical Analysis}

All calculations were performed using Excel 2010. GenStat Release 12.2 for Windows 7 (VSN International Ltd., Hemel Hempstead, Hertfordshire, UK) was used to determine the accumulated analysis of variance. The mean values were compared using LSD Tukey's method ( $p<$ $0.05)$. 


\section{Results and Discussion}

The variegated cultivar contained higher amounts of dry matter, ranging from $12.6 \%-13.4 \%$ for the leaves, and from $8.9 \%-9.9 \%$ for the stems, compared to the green cultivar (Table 1). For both cultivars, the stems contained higher amounts of moisture than the leaves.

The moisture content of sorrel was much higher than the reported moisture content of Rumex acetosa plants grown in Nigeria [7] but the levels found in the green and variegated cultivars were comparable to other tender and succulent green leafy vegetables [18]; the green sorrel sprouts had moisture contents very similar to lettuce [18]. The large green sorrel leaves were almost twice the length of the large variegated leaves. The length of the leaves of the variegated cultivar ranged from 76.7 - 166.9 $\mathrm{mm}$ while the green cultivar leaves ranged from 108.7 $311.7 \mathrm{~mm}$.

The total oxalate content in the sorrel leaves ranged from $273.0-953.8 \mathrm{mg} / 100 \mathrm{~g}$ wet matter (WM), and the soluble oxalates from $42.0-124.8 \mathrm{mg} / 100 \mathrm{~g}$ WM. These values were comparable with the results for Rumex acetosa and other Rumex species presented earlier [10,19, 20]. Seiner et al. [21] reported the highest amounts of total and soluble oxalates in sorrel amounting to 1391 $\mathrm{mg} / 100 \mathrm{~g} \mathrm{WM}$ and $258 \mathrm{mg} / 100 \mathrm{~g} \mathrm{WM}$, respectively. In contrast, the lowest reported amounts of total and soluble oxalates in sorrel leaves were lower than $1.0 \mathrm{mg} / 100 \mathrm{~g}$ WM [7]. The discrepancies in the values obtained can be ascribed to several factors such as soil conditions, climate, species or cultivar, maturity and methods of analysis. Also, the size of the leaves used in these earlier studies was not recorded. The total oxalate content of the stems in this present study ranged from 334.9 - 491.6 $\mathrm{mg} / 100 \mathrm{~g} \mathrm{WM}$ and from $53.9-83.6 \mathrm{mg} / 100 \mathrm{~g} \mathrm{WM}$ for soluble oxalates. As a percentage of total oxalates, the soluble oxalates ranged from $10.4 \%-24.3 \%$.

Statistical analyses showed that the differences in oxalate content between the plant parts of sorrel were statistically significant at $p<0.05$. It was evident that three factors, namely, cultivar, plant part and size, all affected

Table 1. Mean length ( $\mathrm{mm} \pm \mathrm{SE}), \%$ dry matter, total, soluble and insoluble oxalates (mg/100g WM \pm SE) of green and variegated leaves and stems and, in brackets, \% soluble oxalates of total oxalates.

\begin{tabular}{|c|c|c|c|c|c|c|c|c|c|c|}
\hline \multicolumn{3}{|c|}{ Plant part Length } & \multicolumn{2}{|c|}{$\%$ Dry matter } & \multicolumn{2}{|c|}{ Total oxalate } & \multicolumn{2}{|c|}{ Soluble oxalate } & \multicolumn{2}{|c|}{ Insoluble oxalate } \\
\hline & Green & Variegated & Green & Variegated & Green & Variegated & Green & Variegated & Green & Variegated \\
\hline \multicolumn{11}{|l|}{ Leaves } \\
\hline Small & $108.7 \pm 6.4$ & $76.7 \pm 4.4$ & 7.2 & 12.6 & $273.0 \pm 5.4$ & $739.8 \pm 7.8$ & $\begin{array}{c}42.0 \pm 0.5 \\
\quad(15.4)\end{array}$ & $\begin{array}{c}106.9 \pm 0.3 \\
(14.5)\end{array}$ & $231.0 \pm 5.9$ & $632.9 \pm 8.1$ \\
\hline Medium & $157.5 \pm 10.0$ & $108.7 \pm 7.2$ & 6.8 & 13.4 & $386.3 \pm 3.0$ & $953.8 \pm 10.2$ & $\begin{array}{c}47.1 \pm 0.3 \\
\quad(12.2)\end{array}$ & $\begin{array}{c}113.5 \pm 0.8 \\
\quad(11.9)\end{array}$ & $339.2 \pm 3.3$ & $840.4 \pm 10.9$ \\
\hline Large & $311.7 \pm 11.9$ & $166.9 \pm 2.5$ & 6.5 & 12.7 & $684.8 \pm 13.2$ & $660.6 \pm 10.8$ & $\begin{array}{c}71.3 \pm 1.2 \\
(10.4)\end{array}$ & $\begin{array}{c}124.8 \pm 0.7 \\
(18.9)\end{array}$ & $613.6 \pm 12.0$ & $535.8 \pm 11.5$ \\
\hline \multicolumn{11}{|l|}{ Stems } \\
\hline Small & - & - & 4.3 & 8.9 & $403.4 \pm 2.1$ & $419.6 \pm 16.6$ & $\begin{array}{l}59.5 \pm 0.2 \\
\quad(14.8)\end{array}$ & $\begin{array}{c}83.6 \pm 0.4 \\
(19.9)\end{array}$ & $343.8 \pm 4.6$ & $335.9 \pm 17.0$ \\
\hline Medium & - & - & 4.3 & 9.9 & $375.5 \pm 4.2$ & $334.9 \pm 6.2$ & $\begin{array}{c}59.4 \pm 0.5 \\
15.8)\end{array}$ & $\begin{array}{c}81.5 \pm 0.3 \\
(24.4)\end{array}$ & $316.1 \pm 4.6$ & $253.3 \pm 5.9$ \\
\hline Large & $-{ }^{a}$ & - & 4.5 & 9.1 & $424.4 \pm 1.0$ & $491.6 \pm 3.3$ & $\begin{array}{c}53.9 \pm 0.3 \\
(12.7)\end{array}$ & $\begin{array}{c}80.2 \pm 0.4 \\
\quad(16.3)\end{array}$ & $370.6 \pm 0.7$ & $411.4 \pm 2.9$ \\
\hline \multicolumn{3}{|c|}{ Analysis of Variance d.f. } & & & \multicolumn{2}{|c|}{ Total } & \multicolumn{2}{|c|}{ Soluble } & \multicolumn{2}{|c|}{ Insoluble } \\
\hline Cultivar & & 1 & & & \multicolumn{2}{|r|}{ * } & \multicolumn{2}{|c|}{$*$} & \multicolumn{2}{|c|}{ * } \\
\hline \multicolumn{2}{|c|}{ Plant part } & 1 & & & \multicolumn{2}{|r|}{ * } & \multicolumn{2}{|r|}{ * } & \multicolumn{2}{|c|}{ * } \\
\hline \multicolumn{2}{|c|}{ Size } & 2 & & & \multicolumn{2}{|r|}{ * } & \multicolumn{2}{|r|}{ * } & \multicolumn{2}{|c|}{ * } \\
\hline \multicolumn{2}{|c|}{ Cultivar $\times$ Plant part } & 1 & & & \multicolumn{2}{|r|}{ * } & \multicolumn{2}{|r|}{ * } & \multicolumn{2}{|c|}{ * } \\
\hline \multicolumn{2}{|c|}{ Cultivar $\times$ Size } & 2 & & & \multicolumn{2}{|c|}{ ns } & \multicolumn{2}{|c|}{$\mathrm{ns}$} & \multicolumn{2}{|c|}{ ns } \\
\hline \multicolumn{2}{|c|}{ Plant part $\times$ Size } & 2 & & & \multicolumn{2}{|r|}{ * } & \multicolumn{2}{|r|}{ * } & \multicolumn{2}{|c|}{ * } \\
\hline Cultivar $\times \mathrm{F}$ & nt part $\times$ Size & 1 & & & & ns & & ns & & is \\
\hline $\mathrm{LS}$ & $(5 \%)$ & & & & & 3.1 & & 0.2 & & 3.9 \\
\hline
\end{tabular}

${ }^{a}$ Not measured; Significance: ns, not significant; ${ }^{*} p<0.05$; LSD: least significant difference. 
the amount of oxalates present in the sorrel leaves and stems. The interactions between cultivar and plant part, and size and plant part were both statistically significant $(p<0.05)$. However, there were no significant differences observed based on the two-factor interaction of cultivar and size or the three-factor interaction of cultivar, plant part, and size.

Overall, the variegated cultivar contained more oxalates in its leaves than in the green cultivar leaves, although the green cultivar had longer leaves (Table 1). The presence of the dark red colouring in the leaves and higher oxalates in the variegated cultivar may signify a positive correlation between the leaf colour and the accumulation of oxalates in plants [22]. Two studies have reported that oxalates were not equally distributed between the plant parts $[14,23]$. For sorrel, oxalates were more abundant in the leaves than in the stems regardless of the cultivar. This characteristic was also observed in plants belonging to the Polyganaceae and Amaranthaceae families such as rhubarb, spinach, amaranth and beet [10].

The least significant difference values in the sorrel at $(\mathrm{p}<0.05)$ were $133.1 \mathrm{mg} / 100 \mathrm{~g}$ WM for the total oxalate, and $10.2 \mathrm{mg} / 100 \mathrm{~g} \mathrm{WM}$ for the soluble oxalate. The size had no significant effect on the oxalate content of the stems because the differences between the means were lower than the LSD values. For the green sorrel leaves, the oxalate content increased linearly with increased size. However, using the LSD values as the bases of comparison, the differences between the levels of oxalates in small and medium leaves were not statistically significant. The levels of oxalates in the variegated leaves were highest in the medium leaves and lower in the large leaves. This may be due to the role of oxalates as a calcium reservoir, which releases calcium as needed by the plant for its growth [11]. Overall, the results showed that the soluble oxalate contents of both sorrel cultivars were positively correlated with leaf size.

The green sorrel sprouts contained both leaves and stems and a few un-sprouted seeds (Table 2). The levels of total and soluble oxalates in this sample were very high and this may have occurred because the plant seeds resent contained high amounts of oxalates [23]. Raw immature sorrel leaves are eaten mixed with salads and in sandwiches while the larger more mature leaves are often prepared as soups and pesto. The reduction of oxalates in both the soup and pesto products occurred mainly because other food materials were added to make the soup which, essentially, diluted the oxalate content of the sorrel leaves (Table 2). The soup contained 70.1 $\mathrm{mg} / 100 \mathrm{~g} \mathrm{WM}$ of total oxalates and $12.7 \mathrm{mg} / 100 \mathrm{~g} \mathrm{WM}$ of soluble oxalates. The homemade pesto had a higher total oxalate content amounting to $88.0 \mathrm{~g} / 100 \mathrm{~g}$ WM as compared to $20.1 \mathrm{mg} / 100 \mathrm{~g} \mathrm{WM}$ of total oxalate present in the commercial pesto. However, the soluble oxalate contents
Table 2. Mean percentage dry matter, total, soluble, and insoluble oxalate content $(\mathrm{mg} / 100 \mathrm{~g} W M \pm \mathrm{SE})$ of sorrel sprouts, soup and pesto and soluble oxalate per serving of pesto (mg/25g) and soup (mg/250g).

\begin{tabular}{cccccc}
\hline Sample & $\begin{array}{c}\text { Dry } \\
\text { matter } \\
(\%)\end{array}$ & $\begin{array}{c}\text { Total } \\
\text { oxalate }\end{array}$ & $\begin{array}{c}\text { Soluble } \\
\text { oxalate }\end{array}$ & $\begin{array}{c}\text { Insoluble } \\
\text { oxalate }\end{array}$ & $\begin{array}{c}\text { Soluble } \\
\text { oxalate } \\
(\mathrm{mg} / 100 \mathrm{~g} \mathrm{WM})\end{array}$ \\
\hline Sprouts & 4.8 & $797.0 \pm 2.2$ & $104.3 \pm 1.0$ & $693.4 \pm 4.6$ & 26.1 \\
Soup & 14.0 & $70.1 \pm 1.2$ & $12.7 \pm 0.1$ & $57.42 \pm 1.2$ & 31.7 \\
Pesto & & & & & \\
Homemade & 57.1 & $88.0 \pm 0.1$ & $15.6 \pm 0.2$ & $72.3 \pm 0.3$ & 3.9 \\
Commercial & 74.0 & $20.1 \pm 0.5$ & $15.8 \pm 0.4$ & $4.7 \pm 0.4$ & 3.9 \\
\hline
\end{tabular}

in both types of pesto were almost equal. While sorrel pesto and sorrel soup contained lower oxalate levels due to dilution by the addition of other ingredients, incorporating parmesan cheese in pesto and sour cream in soup also provided calcium, which can effectively reduce the soluble oxalates by conversion to insoluble oxalates [24]. Parmesan cheese would supply calcium in the pesto and the sour cream would supply calcium in the soup recipe. The soluble oxalate content in the pesto was higher because it contained a higher proportion of sorrel leaves. Soup preparation involved cooking and this may have facilitated the leaching of soluble oxalates from the sorrel leaves, thus allowing the soluble oxalates to combine with calcium, from the sour cream, and form insoluble oxalates, which will not be absorbed from the digestive tract after ingestion [24].

It is useful to present the analysis of sorrel pesto and sorrel soup on a per serving basis. A standard serving size for vegetables is a cup-full (a standard cup contains $250 \mathrm{~g}$ ) while $25 \mathrm{~g}$ is used for a condiment like pesto [25]. The soluble oxalate per serving was similar for the commercial and home-made pesto while the sorrel soup contained the highest amount of soluble oxalates per serving $(31.7 \mathrm{mg} / 250 \mathrm{ml})$ simply because the serving size was ten times higher than that of the pesto. The levels of oxalates in sorrel soup and sorrel pesto per serving were low and within the normal dietary intake of $50-200 \mathrm{mg}$ of oxalates/day [26] and a long way below the minimum lethal dose of $4-5 \mathrm{~g}$ total oxalates/day [27,28]. Although more pesto may be consumed than the recommended serving size, other oxalate sources in the daily diet should also be noted, to avoid the consumption of too much oxalate in the diet.

\section{Conclusion and Recommendations}

The soluble oxalate content of sorrel leaves increases linearly with the length or size of the leaves. The relationship between the leaf size and maturation stages in 
determining the oxalates in plants needs further investigation. Sorrel sprouts contain high levels of oxalates but these are only added as a garnish to foods and not eaten in large amounts. As sorrel is a high oxalate-containing food, it should only be consumed in small amounts especially by people who are prone to kidney-stone formation [29]. It is also advisable to prepare sorrel with other calciumrich foods to reduce the soluble oxalate content, thus reducing the amount of oxalate absorbed into the body [24]. Pesto is an ideal way of preparing sorrel as the serving size is small, so low levels of oxalates will be ingested. Further work is required to determine the best method to prepare sorrel soup and pesto to give a good flavor while maintaining a low soluble oxalate content.

\section{Acknowledgements}

The authors wish to thank Leo Vanhanen for his help throughout the experiment and Janette Busch for proof reading the text.

\section{REFERENCES}

[1] X. Y. Yu, X. H. Tan and W. Cai, "Survey on Polyganaceae Herb Resources of in Zhejiang Tiantong National Forest Park," Medicinal Plants, Vol. 2, No. 3, 2011, pp. 22-24, 27.

[2] D. Bensky and A. Gamble, "An Encyclopaedia of Traditional Chinese Medicinal Substances (Zhong Yao Da Ci Dian)," Eastland Press, Seattle, 1986.

[3] Z. Kuceková, J. Mlček, P. Humpolíček, O. Rop, P. Valasek and P. Saha, "Phenolic Compounds from Allium schoenoprasum, Tragopogon pratensis and Rumex acetosa and their Antiproliferative Effects," Molecules, Vol. 16, No. 11, 2011, pp. 9207-9217. doi:10.3390/molecules16119207

[4] D. Moravčíková, Z. Kuceková, J. Mlček, O. Rop and P. Humpolíček, "Compositions of Polyphenols in Wild Chive, Meadow Salsify, Garden Sorrel and Ag Yoncha and Their Anti-Proliferative Effect," Acta Universitatis Agriculturae et Silviculturae Mendelianae Brunensis, Vol. 60, No. 3, 2012, pp. 125-132.

[5] K. Gescher, A. Hensel, W. Hafezi, A. Derksen and J. Kühn, "Oligomeric Proanthocyanidins from Rumex acetosa L. Inhibit the Attachment of Herpes Simplex Virus Type-1," Antiviral Research, Vol. 89, No. 1, 2011, pp. 918. doi:10.1016/j.antiviral.2010.10.007

[6] C. S. Holm, J. W. Aston and K. Douglas, "The Effects of the Organic Acids in Cocoa on the Flavour of Chocolate," Journal of the Science of Food and Agriculture, Vol. 61, No. 1, 1992, pp. 65-71. doi:10.1002/jsfa.2740610111

[7] O. Ladeji and Z. S. C. Okoye, "Chemical Analysis of Sorrel Leaf (Rumex Acetosa)," Food Chemistry, Vol. 48, No. 2, 1993, pp. 205-206. doi:10.1016/0308-8146(93)90059-O

[8] S. W. Souci, W. Fachmann and H. Kraut, "Food Composition and Nutrition Tables," CRC Press, Stuttgart, 2000.
[9] N. D. Obretenova, K. Kepova, N. Petrova and K. K'rdzhieva, "Chemical Composition and Nutritive Value of Some Little-Used Leaf Vegetables in Bulgaria," Izvestiya na Institut po Khranene, Vol. 5-20, 1973, pp. 327-332.

[10] S. C. Noonan and G. P. Savage, "Oxalate Content of Foods and Its Effect on Humans," Asia Pacific Journal of Clinical Nutrition, Vol. 8, No. 1, 1999, pp. 64-74. doi:10.1046/j.1440-6047.1999.00038.x

[11] P. A. Nakata, "Advances in our Understanding of Calcium Oxalate Crystal Formation and Function in Plants," Plant Science, Vol. 164, No. 6, 2003, pp. 901-909. doi:10.1016/S0168-9452(03)00120-1

[12] M. Contreras-Padilla, E. Perez-Torrereo, M. HernandezUrbiola, G. Hernandez-Quevedo, A. del Real, E. RiveraMunoz and M. Rodriguez-Garcia, "Evaluation of Oxalates and Calcium in Nopal Pads (Opuntia ficusindica var. redonda) at Different Maturity Stages," Journal of Food Composition and Analysis, Vol. 24, No. 1, 2001, pp. 38-43. doi:10.1016/j.jfca.2010.03.028

[13] T. S. Simpson, G. P. Savage, R. Sherlock and L. P. Vanhanen, "Oxalate Content of Silver Beet Leaves (Beta vulgaris var. cicla) at Different Stages of Maturation and the Effect of Cooking with Different Milk Sources," Journal of Agriculture and Food Chemistry, Vol. 57, No. 22, 2009, pp. 10804-10808. doi:10.1021/jf902124w

[14] S. T. Kareno, M. J. S. Morley-Bunker and G. P. Savage, "Oxalate Content of Purslane Regrowth is Unaffected by Differing Repeat Harvesting Regimes," Proceedings of the Nutrition Society of New Zealand, Vol. 33, 2008, pp. 126-131.

[15] AOAC, "Official Methods of Analysis International," 17th Edition, Association of Analytical Communities, Gaithersburg, 2002.

[16] G. P. Savage, L. Vanhanen, S. M. Mason and A. B. Ross, "Effect of Cooking on the Soluble and Insoluble Oxalate Content of Some New Zealand Foods," Journal of Food Composition and Analysis, Vol. 13, No. 3, 2000, pp. 201206. doi:10.1006/jfca.2000.0879

[17] W. D. Holloway, M. E. Argall, W. T. Jealous, J. Lee and J. H. Bradbury, "Organic acids and Calcium Oxalate in Tropical Root Crops," Journal of Agriculture and Food Chemistry, Vol. 37, No. 2, 1989, pp. 337-341. doi:10.1021/jf00086a014

[18] Food Standards Australia New Zealand, 2010. http://www.foodstandards.gov.au

[19] M. A. Alfawaz, "Chemical Composition of Hummayd (Rumex vesicarius)," Journal of Food Composition and Analysis, Vol. 19, No. 6-7, 2006, pp. 552-555. doi:10.1016/j.jfca.2004.09.004

[20] F. Ferreres, V. Ribeiro, A. G. Izquierdo, M. A. Rodrigues, R. M. Seabra, P. B. Andrade and P. Valentao, "Rumex induratus Leaves: Interesting Dietary Source of Potential Bioactive Compounds," Journal of Agriculture and Food Chemistry, Vol. 54, No. 16, 2006, pp. 5782-5789. doi:10.1021/jf0613233

[21] R. Seiner, R. Honow, A. Seidler, S. Voss and A. Hesse, "Oxalate Contents of Species of the Polyganaceae, Amaranthaceae and Chenopodiaceae Families," Food Chem- 
istry, Vol. 98, No. 2, 2006, pp. 220-224. doi:10.1016/j.foodchem.2005.05.059

[22] N. Suyama, S. Tone and T. Sakai, "Differences of Oxalic Acid Content among Cultivars in Spinach Leaf Blades (Spinacia oleracea L.) by the Leaf Disk Method," Bulletin of the Yamaguchi Agriculture Experimental Station, Vol. 47, 1996, pp. 41-46.

[23] E. Tillman-Sutela and A. Kauppi, "Calcium Oxalate Crystals in the Mature Seeds of Norway Spruce, Picea abies (L.) Karst," Trees, Vol. 13, No. 3, 1999, pp. 131-137. doi:10.1007/s004680050197

[24] G. P. Savage, Martensson and J. R. Sedcole, "Composition of Oxalates in Baked Taro (Colocasia esculenta var. Schott) Leaves Cooked Alone or with Additions of Cows milk or Coconut Milk," Journal of Food Composition and Analysis, Vol. 22, No. 1, 2009, pp. 83-86. doi:10.1016/j.jfca.2008.05.011

[25] "The Concise New Zealand Food Composition Tables," 8th Edition, Plant \& Food Research, Ministry of Health, Wellington, 2009.

[26] R. P. Holmes, H. O. Goodman and D. G. Assimos, "Dietary Oxalate and its Intestinal Absorption," Scanning Microbiology, Vol. 9, No. 4, 1995, pp. 1109-1120.

[27] D. W. Fassett, "Oxalates," In: Toxicants Occurring Naturally in Foods, National Academy of Sciences, Washington DC, 1973, pp. 346-362.

[28] P. P. Figdor, "Uremia as a Symptom of Oxalic Acid Poisoning (in German with English Abstract)," Wiener Medizinische Wochenschrift, Vol. 111, 1961, pp. 111-114.

[29] S. C. Morrison, G. P. Savage, "Oxalates," In: B. Caballero, L. C. Trugo and P. M. Finglas, Eds., Encyclopaedia of Food Sciences and Nutrition, 2nd Edition, Academic Press, London, 2003, pp. 4282-4287. doi:10.1016/B0-12-227055-X/01378-X 